\title{
Empirical Evaluation of Construction Material Waste Generated on Sites in Nigeria
}

\author{
Adewuyi, T.O. ${ }^{*}$, Idoro, G.I. ${ }^{2}$, and Ikpo, I.J. ${ }^{3}$
}

\begin{abstract}
The study investigates the level of construction material waste generated on building sites in South-South, Nigeria. The objective is to empirically establish the level of waste generated on building sites and compare such with the allowable value in estimates. Data were collected from 30 on-going public building projects for six months. The level of material waste was calculated in percentages while one way ANOVA was employed to compare the waste values among the States in the zone. The significant difference between actual and allowable values of waste was tested using paired t-test. The level of material waste was found to be 11.69, $12.10,10.45,14.54$, and 12.07 for concrete blocks, steel reinforcement, timber, and tiles respectively. It was concluded that these values are significantly different, with $p$-values $<0.05$, from the allowable waste. The study recommends that the values of waste derived by this study be adopted in estimates.
\end{abstract}

Keywords: Actual waste; allowable waste; building sites; empirical evaluation; material waste.

\section{Introduction}

Generally, construction sector embraces both civil engineering and building works. In Nigeria, the construction sector represents the largest employer of labour (directly or indirectly) in the private sector, and thus forms a crucial focus of the national economy [1]. The contribution of the construction industry to the growth of the Gross Domestic Product (GDP) of Nigeria is steady and improving; from about 5\% in 2001 to over $13 \%$ in 2007 [2]. This growth is motivated by continued interest of government to reposition Nigeria's economy as one of the top 20 largest economies in the world. Interestingly, the government is responsible for about $75 \%$ of infrastructure development in Nigeria [3]. Evidently, there is very strong relationship between the Nigerian construction industry and larger economies, both in Nigeria and Africa at large. Whatever happens to the industry will directly or indirectly influence other industries and ultimately the wealth of the country [1,2]. The third quarter estimate in the year 2011 shows that Nigeria's construction sector accounts for $1.4 \%$ of its GDP [4].

${ }^{1}$ Department of Building, Faculty of Environmental Studies, University of Uyo, Uyo, NIGERIA.

${ }^{2}$ Department of Building, Faculty of Environmental Sciences, University of Lagos, Akoka, Lagos, NIGERIA.

${ }^{3}$ Department of Building, Faculty of Environmental Design and Management, Obafemi Awolowo University, lle Ife, NIGERIA.

*Corresponding author; e-mail: timadetimade@yahoo.com

Note: Discussion is expected before November, $1^{\text {st }} 2014$, and will be published in the "Civil Engineering Dimension" volume 17, number 1, March 2015.

Received 08 November 2013; revised 23 January 2014; accepted 10 July 2014.
Material contributes significantly to the cost of construction project, therefore material wastage has adverse impact on construction cost, contractor's profit margin, construction duration and can be a possible source of dispute among parties to a project. The cost of material waste generated on building sites represents avoidable cost in construction which can either be eliminated or reduced. Excessive wastage of raw materials, improper waste management and low awareness of the need for waste reduction are major difficulties in minimising waste in the construction industry [5]. The cost reduction achieved by preventing the generation of construction waste is equally of direct benefit to most of the participants that work on a construction project. Hoe [6] stated that the extent to which waste can be prevented in the construction industry has been a long-debated issue. Whereas it is impossible to completely eliminate all wastage, the concern should be how practices in the local industry can be managed to minimise waste, especially in Nigeria where industrialised building techniques have not been appreciably embraced.

Enshassi et al. [7] reported waste rate of materials as an indicator of project performance. In the study, conducted in Gaza Strip, Palestine, waste rate of materials was ranked in the ninth, thirteenth and fifteenth positions among the seventeen indicators in the cost criteria by three different group of respondents (i.e. owner, contractor, and consultant) respectively. According to Fellows et al. [8], materials usually account for between one-third and one-half of the cost of a building project. Smaller firms, whose size precludes the use of bulk, centralised purchasing, will have a proportionally higher cost of 
materials as they cannot obtain the discounts and credit facilities enjoyed by larger firms. The second important aspect of materials cost is concerned with measurement and estimating. Thirdly, waste of materials is a significant source of unrecovered cost (and hence loss). Fellows et al. [8] showed that an insufficient allowance in the estimate for waste of materials can completely erode anticipated profit.

The entire local studies available on level of material waste generated on site are primarily based on perceptions of the stakeholders in the industry, except Olomolaiye [9] that augmented the administration of questionnaire with interview. It suffices therefore to empirically establish the actual level of material waste on site.

The aim of the study is to investigate the extent/level of material waste generated during the construction of building projects in South-South of Nigeria with a view to improving the performance of construction projects in Nigeria. To achieve this aim, the study has the following objectives:

(i) To empirically establish the level of construction material waste generated on building sites.

(ii) To compare the actual material waste generated on building sites among the six States in South-South of Nigeria.

(iii) To compare the actual level of material waste generated on site with estimator's allowance.

Two hypotheses, arising from objectives (ii) and (iii), were postulated for the study.

$\mathrm{H}_{1}$ : There is no significant variation in the level of material waste generated on selected building sites among the six States of South-South, Nigeria.

$\mathrm{H}_{2}$ : There is no significant difference between the actual and the allowable material waste generated on building sites of South-South, Nigeria.

Several studies have been carried out in different countries as regards the characteristics and amount of construction material waste generation while some countries are yet to pay particular attention to the issue. The magnitude of waste on construction sites is considerable. Studies showed that the waste rate was different between developed countries and developing countries [10].

Bossink and Brouwers [10] found in the Netherlands that the amount of waste for each building material lies between $1 \%$ and $10 \%$ of the amount purchased, depending on type of material. Furthermore, it was concluded that an average of $9 \%$ (by weight) of the total purchased construction materials end up as site waste in the Netherlands. Construction and demolition waste in Hong Kong is a major problem due to the high population density, the scarce availability of space and the development in economics and infrastructure [11]. According to Poon et al. [12], research in Hong Kong indicated that about $5-10 \%$ of building materials end up as waste on building sites. There are many contributory factors to this figure, both human and mechanical, and others.

In the UK, a recent research indicated that at least $10 \%$ of all raw materials delivered to most sites are wasted through damage, loss and over-ordering [13]. Studies in the USA, Scandinavia and UK suggest that up to $30 \%$ of construction is rework. Labour is used at only 40 to $60 \%$ of potential efficiency. Accidents can account for 3 to $6 \%$ of total project costs, and at least $10 \%$ material waste [14]. Often $10-15 \%$ unfinished work may be due to problems emerging during the task execution such as a sudden breakdown of tools and technical problems [15].

In developing countries (Tanzania, Zambia, Zimbabwe and Botswana) the followings are estimated; $40 \%$ of construction is rework, 30 to $40 \%$ labour potential is used, $8 \%$ of total project costs account for accidents and 20 to $25 \%$ of materials are wasted [14]. On the other hand, studies show that the waste rate in the Brazilian construction industry is 20 to $30 \%$ of the weight of total materials on site [16].

In Greece, each $1000 \mathrm{~m}^{2}$ of building activity entail the generation of $50 \mathrm{~m}^{3}$ of waste [17]. On average, workers spend only $46 \%$ of working time on the value adding activities, $15 \%$ on the essential contributory and the rest $39 \%$ on the waiting and idling [18].

Olomolaiye et al. [19] discovered 43 percent unproductive time on construction sites in Nigeria while Olomolaiye [9] asserted that excessive materials wastage in Nigerian construction industry was due to improper management. Akinkurolere and Franklin [20] observed that manual labour is more extensively employed in most Nigerian construction firms in handling and transportation of materials, including the fragile ones, and the belief that the cost of recycling and reusing of waste is prohibitive. Dania et al. [21] discovered that the site waste management in Nigeria is very poor based on professionals' perception, while Akanni [22] found 13.6 percent wastage level of material in Nigerian construction industry. Oladiran [23] noted that 36.7 percent of professionals in construction companies rarely use waste management plans, while 13.3 percent never used it. Odusami et al. [24] posited that the levels of material wastage on site are higher than estimators' allowances for most materials. Wahab and Lawal [25] advocated for effective control of materials from design to construction stage so as 
to adequately reduce processes that can lead to wastages in construction. This study empirically investigated the problems of construction material waste in Nigerian construction industry focusing on five types of the most commonly used materials in almost every type of building project, namely concrete, blocks, reinforcement, timber and tiles.

\section{Study Area}

Nigeria is divided into six geo-political zones. The South-South of Nigeria comprises of Akwa-Ibom, Bayelsa, Cross-River, Delta, Edo, and Rivers States and is geographically located within the Niger Delta region of Nigeria as shown in Figure 1. Osaghae et al. [26] described the Niger-delta as an area comprising of coastal low lands and watersmarshland, creeks, tributaries, and lagoons of the southernmost ends of Nigeria that drain the Niger River into the Atlantic at the Bight of Biafra. The study area, Niger-Delta is one of the largest deltas in the world covering a land mass of over $29,100 \mathrm{~km}^{2}$. It lies between longitude $5.05^{\circ} \mathrm{E}$ and $7.35^{\circ} \mathrm{E}$ and latitude $4.15^{\circ} \mathrm{N}$ and $6.01^{\circ} \mathrm{N}$.

Adewuyi [27] reported the commonness of the use of "half-baked" skilled artisans in the study area due to pressure groups from among the youths resulting to high waste of construction materials. It was observed that this factor accounted for high rate of rework which has been established by many authors as a key source of material waste generation in the construction industry. Furthermore, the usually prolonged severe weather condition in terms of a high rainfall of the area was established to be a significant contributing factor to material waste generation on building sites [27].
The general terrain of the area is responsible for the incessant bad condition of roads which makes transportation of construction materials difficult and expensive. Additionally, some of the materials are not readily available in some parts of the zone. For example, the coarse aggregates used in Rivers State are transported from the northern part of Cross River State which is a distance of about $300 \mathrm{~km}$ apart. Poor road condition is known to be a factor contributing to construction material waste as materials are lost in transit during transportation, especially aggregate [27]. This research focused on this area due to numerous on-going building construction works which may be attributed to a significant increase of revenue from the Federation Account allocated to these States sequel to the nation's wealth derived from the region.

\section{Method}

To achieve the objectives of this study, data were collected on five building materials namely: concrete, blocks, timber (formwork), steel reinforcement, and tiles. A pilot survey by Adewuyi [27] revealed that there were 63 on-going public building projects in the year 2011 in the study area. Thirty (30), with five (5) in each State, among the on-going projects were purposively sampled for data collection through research assistants for six months period (October 2011 - March 2012) using the research instrument (Work study manual) developed for the purpose [27]. The daily activities involving the use of each of these materials in each of the selected sites were monitored by the research assistants using the research instrument for collection of required data that enabled the extraction of the data needed for the study.

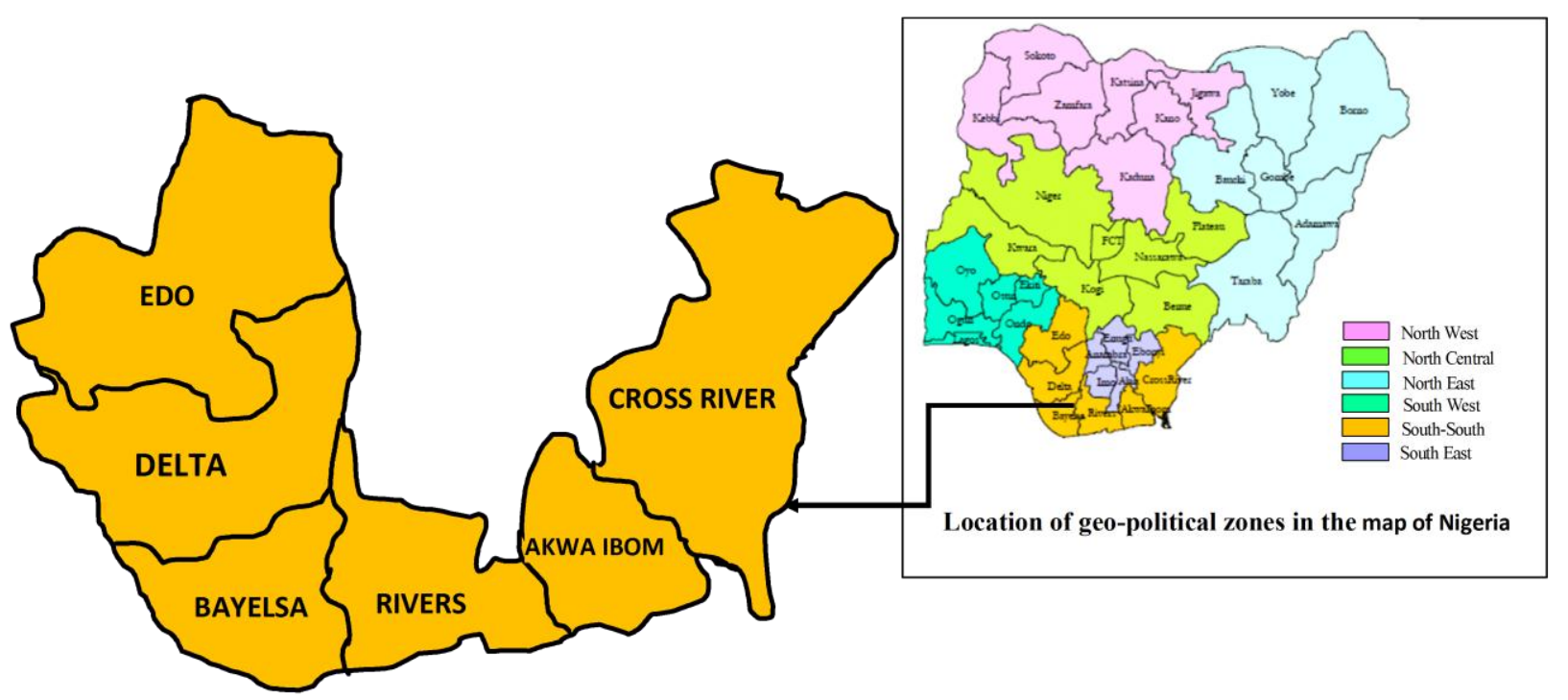

Figure 1. Map of South-South Geo-political zone in Nigeria 
To establish the amount of material waste occurring on-site, the initial quantities of materials started with at the onset of the activity and the left over quantities at the close of work were recorded to ascertain the actual quantities used and the volume of the day's work were measured. The quantities were measured by volume and weight for concrete and reinforcement respectively while blockwork, formwork and tiling were measured in area. Secondly, the theoretical quantities for the work done were calculated with the aid of formatted Microsoft Excel software for preparation of bill of quantities. This was achieved by inserting the measured dimensions (the field data) into the software which in turn generates the theoretical quantities involved. This aspect was carried out with the assistance of experienced licensed projects' Quantity Surveyors. These are the quantities described as the theoretical quantities for the work done. The computed quantities were deducted from the actual quantities used on-site and the balance represents the waste which was expressed as a percentage of the theoretical quantities for the work done as expressed in Equation 1.

$\mathrm{W}_{\mathrm{g}}=\frac{\mathrm{Q}_{1}-\mathrm{Q}_{2}}{\mathrm{Q}_{2}} * 100$

where:

$\mathrm{Wg}=$ Waste generated in percentage.

$\mathrm{Q}_{1}=$ Actual quantity used on-site (in volume, weight or area as applicable).

$\mathrm{Q}_{2}=$ Theoretical quantity for the work done (in volume, weight or area as applicable).

To determine the level of waste generated in each of the selected sites in the six States of South-South, the average amount of waste for each of the selected materials were calculated and the result presented in a tabular form for each of the materials. One way analysis of variance (ANOVA) was employed to test hypothesis one while t-test was used to test hypothesis two.

\section{Results and Discussion of Findings}

The results obtained from the analysis of data collected are presented as follows:

\section{Level of Material Waste Generated on Site}

The result of the level of waste generated on building site for each of the five selected materials is presented in Table 1.

The result shows that the level of waste in concrete generated in Akwa Ibom State is the highest which is $12 \%$ while the least is $10.80 \%$ in Rivers State. While highest level of waste in blocks on building site is generated in Edo state with a value of $12.32 \%$, the least is generated in Rivers State being $11.62 \%$ on the average.
Table 1. Material Waste Generated on Building Sites in South-South, Nigeria (\%)

\begin{tabular}{lcccc}
\hline Material type & AKS & BYS CRS DTS EDS & RVS & Average \\
\hline Concrete & 12.00 & 11.8911 .8911 .5611 .97 & 10.80 & 11.69 \\
Blocks & 12.20 & 12.2811 .8812 .2712 .32 & 11.62 & 12.10 \\
Reinforcement & 10.66 & 10.8110 .2710 .8510 .05 & 10.03 & 10.45 \\
Timber & 13.98 & 14.3813 .4914 .9614 .85 & 15.59 & 14.54 \\
Tiles & 12.76 & 12.4411 .4711 .6812 .31 & 11.77 & 12.07 \\
\hline
\end{tabular}

$\mathrm{AKS}=$ Akwa Ibom state; BYS = Bayelsa state; $\mathrm{CRS}=$ Cross River state; DTS = Delta state EDS = Edo state; RVS $=$ Rivers state

The highest material waste in steel reinforcement activities is $10.85 \%$ as found in Delta State while the least value is found in Rivers State being 10.03\%.

The result shows that the highest level of timber waste is found in Rivers State with a value of $15.59 \%$ while the least value is 13.98 in Akwa Ibom State. Material waste in tiling activities indicates the highest value of $12.76 \%$ for Akwa Ibom State while the least value is obtained in Cross River State being $11.47 \%$. The reasons for these discrepancies may be due to variation in operatives' attitude to material handling, double handling and the level of material management provided on site across the different States.

\section{Statistical Test of Level of Material Waste in South-South, Nigeria}

To further explain the level of material waste generated, hypothesis one which states that there is no significant variation in the level of material waste generated on selected building sites among the six States of South-South geo-political zone in Nigeria was tested using one-way ANOVA at $p \geq 0.05$ ( $95 \%$ level of significance). The rule for the rejection of the hypothesis is that when the $p$-value $>0.05$, the test fails to rejects the hypothesis, however, when the p-value $\leq 0.05$, the test rejects the hypothesis. The test was carried out on each of the five materials studied in this research namely: concrete, blocks, steel reinforcement, timber and tiles and results presented in Table 2 .

The results in Table 2 show that the p-value of 0.738 is greater than the critical p-value (0.05) showing insignificant variation among the level of waste generated among the States in concrete in the six States, therefore the test fails to reject the hypothesis. Similarly, the p-values of $0.955,0.880$, 0.450 , and 0.741 , obtained for blocks, reinforcement, timber, and tiles respectively, are greater than the critical p-value (0.05) signifying that there is no variation in the level of waste among the States in each case of the five selected materials. Consequen- 
Table 2. Results of ANOVA test of the level of material waste generated for selected materials among the States in SouthSouth, Nigeria

\begin{tabular}{|c|c|c|c|c|c|c|c|c|}
\hline Material & State & $\mathrm{N}$ & Sum & Mean & F-value & Df & $\mathrm{P}$-value & Decision \\
\hline \multirow[t]{6}{*}{ Concrete } & $\mathrm{AKS}$ & 30 & 360.01 & 12.00 & \multirow{6}{*}{0.550} & 29 & \multirow{6}{*}{0.738} & \multirow{6}{*}{ Accept } \\
\hline & BYS & 30 & 356.67 & 11.89 & & 29 & & \\
\hline & CRS & 30 & 356.79 & 11.89 & & 29 & & \\
\hline & DTS & 30 & 346.93 & 11.56 & & 29 & & \\
\hline & EDS & 30 & 359.00 & 11.97 & & 29 & & \\
\hline & RVS & 30 & 324.00 & 10.80 & & 29 & & \\
\hline \multirow[t]{6}{*}{ Blocks } & AKS & 30 & 365.93 & 12.20 & \multirow{6}{*}{0.218} & 29 & \multirow{6}{*}{0.955} & \multirow{6}{*}{ Accept } \\
\hline & BYS & 30 & 368.44 & 12.28 & & 29 & & \\
\hline & CRS & 30 & 356.49 & 11.88 & & 29 & & \\
\hline & DTS & 30 & 368.04 & 12.27 & & 29 & & \\
\hline & EDS & 30 & 369.7 & 12.32 & & 29 & & \\
\hline & RVS & 30 & 348.64 & 11.62 & & 29 & & \\
\hline \multirow[t]{6}{*}{ Reinforcement } & AKS & 30 & 319.89 & 10.66 & \multirow{6}{*}{0.353} & 29 & \multirow{6}{*}{0.880} & \multirow{6}{*}{ Accept } \\
\hline & BYS & 30 & 324.33 & 10.81 & & 29 & & \\
\hline & CRS & 30 & 308.07 & 10.27 & & 29 & & \\
\hline & DTS & 30 & 325.35 & 10.85 & & 29 & & \\
\hline & EDS & 30 & 301.61 & 10.05 & & 29 & & \\
\hline & RVS & 30 & 300.95 & 10.03 & & 29 & & \\
\hline \multirow[t]{6}{*}{ Timber } & AKS & 30 & 419.45 & 13.98 & \multirow{6}{*}{0.951} & 29 & \multirow{6}{*}{0.450} & \multirow{6}{*}{ Accept } \\
\hline & BYS & 30 & 431.33 & 14.38 & & 29 & & \\
\hline & CRS & 30 & 404.57 & 13.49 & & 29 & & \\
\hline & DTS & 30 & 448.83 & 14.96 & & 29 & & \\
\hline & EDS & 30 & 445.54 & 14.85 & & 29 & & \\
\hline & RVS & 30 & 467.59 & 15.59 & & 29 & & \\
\hline \multirow[t]{6}{*}{ Tiles } & AKS & 30 & 382.7 & 12.76 & \multirow{6}{*}{0.547} & 29 & \multirow{6}{*}{0.741} & \multirow{6}{*}{ Accept } \\
\hline & BYS & 30 & 373.24 & 12.44 & & 29 & & \\
\hline & CRS & 30 & 344.19 & 11.47 & & 29 & & \\
\hline & DTS & 30 & 350.27 & 11.68 & & 29 & & \\
\hline & EDS & 30 & 369.17 & 12.31 & & 29 & & \\
\hline & RVS & 30 & 353.08 & 11.77 & & 29 & & \\
\hline
\end{tabular}

AKS = Akwa Ibom state BYS = Bayelsa state CRS = Cross River state DTS = Delta state EDS = Edo state RVS = Rivers state

tly, the null hypothesis one is accepted and conclusion is made that there is no significant variation in the level of material waste generated on selected building sites among the six States of South-South, Nigeria. The construction method (in-situ) commonly used and the mobility of construction operatives, professionals, and contractors within the study area may be responsible for this result as it reflects the same pattern of construction practices in the level of waste generated among the States.

\section{Comparison between the Actual and Allowable Material Waste}

Allowable values for estimates were sourced for in literature and from licensed practising Quantity Surveyors. An allowance of $7.5 \%$ waste is usually made for concrete mixed on site, $5 \%$ for reinforcement bars cut and bent on site, $10 \%$ for cutting and fixing timber (formwork), 10\% for cutting and laying of blocks and tiles [28]. These allowable values were compared with the respective actual values derived on site.

The percentages of waste generated on site were computed based on the data collected. Detailed chart showing the comparison between the actual and allowable values of material waste in all the States in South-South are depicted in Figure 2. As can be seen from Figure 2, the actual waste quantities generated on site for each of the five selected materials differ greatly from the allowable values in the estimators' accounts.

The result of actual waste generated in concrete works found by this study is similar to the findings of $10.9 \%$ by Swinburne et al. [29] in UK highway construction industry and the report of Bosink and Brouwers [10] of $12 \%$ in Brazilian building industry. Similarly, the results for other materials are comparable with 10-30\% waste by similar studies [10, 30]. 


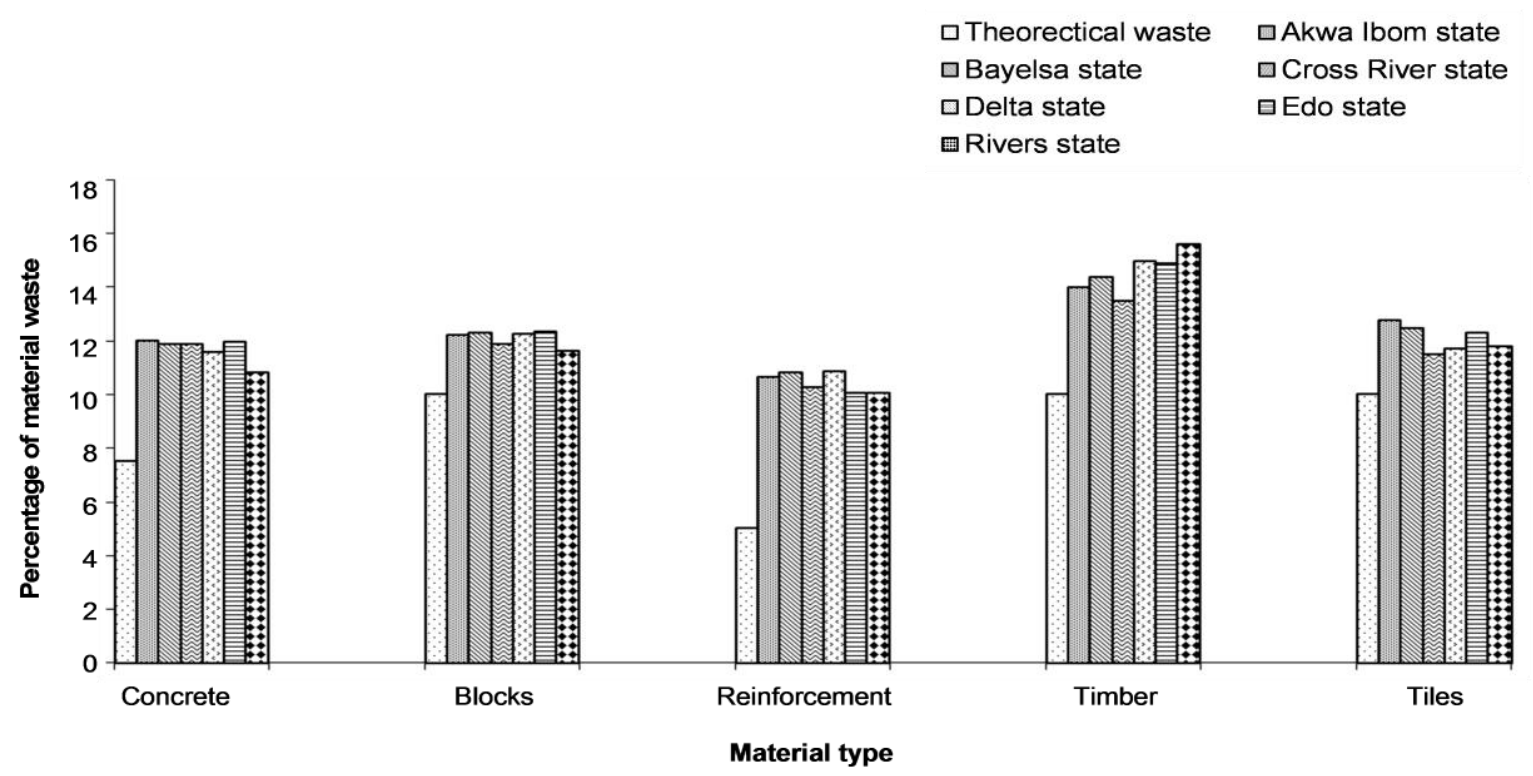

Gambar 2. Description of Difference between Actual Waste on Site and Allowable Value

Table 3. Results of Paired T-test for Test between Actual Waste Generated on Site and the Allowable Values in Estimates

\begin{tabular}{|c|c|c|c|c|c|c|c|}
\hline Variable compared & $\mathrm{N}$ & Mean (\%) & Mean Differences & $\mathrm{t}$ & $\mathrm{df}$ & $\mathrm{P}$-value & Decision \\
\hline \multicolumn{8}{|l|}{ Concrete } \\
\hline Actual waste & 180 & 11.68 & & & & & \\
\hline Theoretical waste & 180 & 7.50 & 4.18556 & 16.613 & 179 & 0.001 & Reject \\
\hline \multicolumn{8}{|l|}{ Blocks } \\
\hline Actual waste & 180 & 12.09 & & & & & \\
\hline Theoretical waste & 180 & 10.00 & 2.09578 & 8.596 & 179 & 0.001 & Reject \\
\hline \multicolumn{8}{|l|}{ Reinforcement } \\
\hline Actual waste & 180 & 10.45 & & & & & \\
\hline Theoretical waste & 180 & 5.00 & 5.44556 & 21.428 & 179 & 0.001 & Reject \\
\hline \multicolumn{8}{|l|}{ Timber } \\
\hline Actual waste & 180 & 14.54 & & & & & \\
\hline Theoretical waste & 180 & 10.00 & 4.54061 & 14.454 & 179 & 0.001 & Reject \\
\hline \multicolumn{8}{|l|}{ Tiles } \\
\hline Actual waste & 180 & 12.07 & & & & & \\
\hline Theoretical waste & & 10.00 & 2.07028 & 7.495 & 179 & 0.001 & Reject \\
\hline
\end{tabular}

Statistical Inferential Comparison between Actual Wastes Generated on Site and the Allowable Value

The data obtained has been drawn from only a small sample of the thousands of building construction carried out in the study area and in Nigeria in particular. The data collected suggests there is a difference, but is it statistically significant? To establish the statistical difference between the actual material waste generated on site and the allowable values provided for in estimates, hypothesis two which states that there is no significant difference between the actual and the allowable material waste generated on building sites of South-South, Nigeria was tested. One hundred and eighty (180) cases of use of each selected materials were recorded. In order to test this hypothesis, paired t-test was used at $p \geq 0.05$ (95\% level of significance). The rule for the rejection of the hypothesis is that when the $p$ value $>0.05$, the test fails to reject the hypothesis, however, when the p-value $\leq 0.05$, the test rejects the hypothesis. The test was carried out on each of the five materials studied in this research. The results are summarised in Table 3.

The results in Table 3 shows that the p-value (0.001) in each case of all the five selected materials is less than the critical p-value (0.05), therefore the test rejects the hypothesis. These results indicate that there is significant difference in the amount of waste generated on building sites and the allowable values 
provided by estimators' account. Hence, the null hypothesis two is rejected and concluded that there is significant difference between the actual amount of waste generated on building sites and the allowable quantities provided in each case of the five selected materials. The construction method, the annual protracted rainy season in the study area and level of material management on site may account for the difference between the actual and allowable waste.

\section{Conclusion and Recommendations}

The study has empirically investigated the level of construction material waste generated on building sites in each State of the study area. The results obtained the level of waste for the five selected materials, namely: concrete, blocks, steel reinforcement, timber and tiles. It was established that there is no significant variation in the level of material waste generated on building sites among the States in the study area. Hence, it is recommended that a uniform percentage allowance for purpose of estimate be adopted for the zone.

The comparison between the actual levels of material waste generated on site and the allowable values shows that there is a statistical significant difference. The actual waste generated on site is found to be higher than the allowable for all the five selected materials. It was concluded that the actual values of material waste generated on sites is significantly different from the allowable provided in estimate. Therefore, there is either the need to adjust the allowable value to mitigate its effect on project cost or contractors should explore control measures to minimise waste. The study recommends that the values of material waste derived by this study should be adopted for the purpose estimate in building works.

\section{References}

1. Ogunsemi, D.R. and Aje, I.O., A Model for Contractors' Selection in Nigeria, Journal of Financial Management of Property and Construction, 11(1), 2006, pp. 33-43.

2. Olatunji. O.A., Due Process and Contractor Selection for Public Works in Nigeria: Building Abroad. Proceedings of the Conference-Workshop on Procurement of Construction and Reconstruction Projects in the International Context, Montreal, Canada, October 23-25, 2008, pp. 385395.

3. BMPIU, Budget Monitoring and Price Intelligences Unit (BMPIU), A Manual on Public Procurement Reform Programme in Nigeria. State House, Abuja, 2005.
4. Oluwakiyesi, T., Construction Industry Report. A Haven of Opportunities, 2011, https://www. proshareng.com/admin/upload/reports/VetivRese archConstructioSectorReportMay2011.pdf

5. Tam, V.W.Y., Tam, C.M., and Ng, W.C.Y., An Examination on the Practice of Adopting Prefabrication for Construction Projects, The International Journal of Construction Management, 7(2), 2007, pp. 53-64.

6. Hoe, L.K., Causal Model for Management of Subcontractors in Waste Minimization, $\mathrm{PhD}$ Thesis, Department of Building, National University of Singapore, Singapore, 2005.

7. Enshassi, A., Mohamed, S., and Abushaban, S., Factors Affecting the Performance of Construction Projects in the Gaza Strip, Journal of Civil Engineering and Management, 15(3), 2009, pp. 269-280.

8. Fellows. R., Langford, D., Newcombe, R., and Urry, S., Construction Management in Practice, Second edition, Blackwell Science Limited, United Kingdom, 2002, pp. 180-181.

9. Olomolaiye, P.O., Materials Management Practice and Waste on Nigerian Building Sites, Building Research and Information, 19(1), 1991, pp. 38-42.

10. Bossink, B.A.G. and Brouwers, H.J.H., Construction Waste: Quantification and Source Evaluation, Journal of Construction Engineering and Management, 122(1), 1996, pp. 55-60.

11. Poon, C.S. and Jaillon, L., A Guide for Minimising Construction and Demolition Waste at the Design Stage, The Hong Kong Polytechnic University, 2002.

12. Poon, C.S., Yu, A.T.W., and Ng, L.H., A Guide for Managing and Minimising Building and Demolition Waste, The Hong Kong Polytechnic University, 2001.

13. Poon, C.S., Yu, A.T.W., Wong, S.W., and Cheung, E., Management of Construction Waste in Public Housing Projects in Hong Kong, Construction Management and Economics, 22(7), 2004, pp. 675-689.

14. Datta, M., Challenges Facing the Construction Industry in Developing Countries, Proceeding of $2^{\text {nd }}$ International Conference on Construction in Developing Countries, Gabarone, Botswana, November 15-17, 2000, http://citeseerx.ist.psu. edu/viewdoc/download?doi=10.1.1.194.6404\&rep =rep1\&type=pdf retrieved February 21, 2011.

15. Koskela, L., Making-Do-The Eighth Category of Waste, Proceedings of the $12^{\text {th }}$ Annual Conference of the International Group for Lean Construction IGLC-12, August, Denmark, 2004. 
16. Formoso, C.T., Soibelman, L., Cesare, C., and Isatto, E.L., Material Waste in Building Industry: Main Causes and Prevention, Journal of Construction Engineering and Management, 128(4), 2002, pp. 316-325.

17. Fatta, D., Papadopoulos, A., Avramikos, E., Sgourou, E., Moustakas, K., Kourmoussis, F., Mentzis, A., and Loizidou, M., Generation and Management of Construction and Demolition Waste in Greece an Existing Challenge, Resources, Conservation and Recycling, 40(1), 2003, pp. 81-91.

18. Zhao, Y., Significant Factors Affecting Construction Productivity, Master's Thesis, Department of Civil Engineering, National University of Singapore, Singapore, 2004.

19. Olomolaiye, P.O., Wahab, K.A., and Price, D.F., Problems Influencing Craftsmen Productivity in Nigeria, Building and Environment, 22(4), 1987, pp. 317-323.

20. Akinkurolere, O.O. and Franklin, S.O., Investigation into Waste Management on Construction Sites in South Western Nigeria. American Journal of Applied Sciences, 2(5), 2005, pp. 980984.

21. Dania, A.A., Kehinde, J.O., and Bala, K., A Study of Construction Material Waste Management Practices by Construction Firms in Nigeria, Proceedings of the $3^{\text {rd }}$ Scottish Conference for Postgraduate Researchers of the Built and Natural Environment, Glasgow, 2007, pp. 121-129.

22. Akanni, P.O., An Empirical Survey of the Effect of Materials Wastage on Contractors' Profit Level in Construction Projects, The Professional Builders: Journal of the Nigerian Institute of Building, 2007, pp. 35-46.

23. Oladiran, O.J., Innovative Waste Management through the Use of Waste Management Plans on Construction Projects in Nigeria, Journal of Architectural Engineering and Design Management, 5(3), 2009, pp. 165-176.
24. Odusami, K.T., Oladiran, O.J., and Ibrahim, S.A., Evaluation of Materials Wastage and Control in some Selected Building Sites in Nigeria, Emirates Journal for Engineering Research, 17(2), 2012, pp. 53-65.

25. Wahab, A.B. and Lawal, A.F., An Evaluation of Waste Control Measures in Construction Industry in Nigeria, African Journal of Environmental Science and Technology, 5(3), 2011, pp. 246-254.

26. Osaghae, E., Ikelegbe, A., Olarinmoye, O., and Okhomina, S., Youth Militias, Self Determination and Resource Control Struggle in the NigerDelta Region of Nigeria. Council for the Development of Social Science Research in Africa (CODESRIA), Consortium for Development Partnership (CDP) Research Report N2, 2008, http://www.codesria.org/IMG/pdf/Nigeria_Rep_2. pdf

27. Adewuyi, T.O., Construction Material Waste Planning and Control Techniques on Building Sites in South-South of Nigeria, PhD Thesis, Department of Building, Faculty of Environmental Studies, University of Uyo, Uyo, Nigeria, 2012.

28. UNESCO-NIGERIA TVE, Technical Vocational Education Instructional Material: Tendering and Estimating II, 2008, pp. 47-77, http://unesconigeriatve.org/download/instructional_ matrials/ nd\%20building\%20technology/Semesters/Semes ter\%204/Qus\%20210\%20Book.pdf retrieved February $26,2012$.

29. Swinburne, J., Udeaja, C.E., and Tait, N., Measuring Material Wastage on Construction Sites: A Case Study of Local Authority Highway Projects, Built and Natural Environment Research Papers, 3(1), 2010, pp. 31-41.

30. Tam, V.W.Y., Shen, L.Y., and Tam, C.M., Assessing the Levels of Material Wastage Affected by Subcontracting Relationships and Projects Types with their Correlations, Built Environment, 42(3), 2007, pp. 1471-1477. 